\title{
INDEX
}

AGLIĆ ALJINOVIĆ, A., PEČARIĆ, J. and RIBIČIĆ PENAVA, M.; Sharp integral inequalities based on general two-point formulae via an extension of Montgomery's identity

AGUSTO, F. B. and OGUNYE, O. R.; Avian influenza optimal seasonal vaccination strategy

AKHTAR, W., FETECAU, C. and AWAN, A. U.; Exact solutions for the Poiseuille flow of a generalized Maxwell fluid induced by time-dependent shear stress

AWAN, A. U.; See AKHTAR, W.

BASSOM, A. P.; See LEACH, J. A.

BASSOM, A. and HOCKING, G.; Editorial

BAXTER, R. J.; Proof of the determinantal form of the spontaneous magnetization of the superintegrable chiral Potts model

CHEN, W.-T. and ZHU, S.-P.; Optimal exercise price of American options near expiry

CHO, G. M., CHO, Y. Y. and LEE, Y. H.; A primal-dual interior-point algorithm based on a new kernel function

CHO, Y. Y.; See CHO, G. M.

CIVAL BURANAY, S.; See DOSIYEV, A. A.

DOSIYEV, A. A. and CIVAL BURANAY, S.; Correction to 'On the order of maximum error of the finite difference solutions to Laplace's equation on rectangles'

DUAN, G. R.; See LI, B.

FETECAU, C.; See AKHTAR, W.

GANI, J. and SWIFT, R. J.; Deterministic and stochastic models for the spread of cholera

GAO, R. and LIU, X.; Optimal control problems for general global hybrid dynamical systems with matrix cost functional

GUO, J.; See LIANG, Z.

HAN, C. and ZHANG, H.; Optimal filtering in discrete-time systems with time delays and Markovian jump parameters

HOCKING, G.; See BASSOM, A.

HUANG, T.-Z.; See LI, J.-L.

KHADER, M. M.; See SWEILAM, N. H.

LAUKO, M. and ŠEVČOVIČ, D.; Comparison of numerical and analytical approximations of the early exercise boundary of American put options

LEACH, J. A. and BASSOM, A. P.; The large-time solution of a nonlinear fourth-order equation initial-value problem I. Initial data with a discontinuous expansive step

LEE, Y. H.; See CHO, G. M. 
LENZ, R. D.; See SELLIER, M.

LI, B., TEO, K. L., ZHAO, G. H. and DUAN, G. R.; An efficient computational approach to a class of minmax optimal control problems with applications

LI, J.-L., HUANG, T.-Z. and LI, L.; Analysis of the inexact Uzawa algorithms for nonlinear saddle-point problems

LI, L.; See LI, J.-L.

LI, M., ZHOU, W., NI, Z. and WANG, M.; Mixed delay-dependent stability of high-order neural networks based on a weak coupling LMI set

LI, R. and SHI, Y. J.; A time-fuel optimal control problem of a cruise missile based on an improved sliding mode variable structure model

LIANG, Z. and GUO, J.; Optimal proportional reinsurance under two criteria: maximizing the expected utility and minimizing the value at risk

LIAO, S.; Series solution of large deformation of a beam with arbitrary variable cross section under an axial load

LIN, X.; See QIAN, Y.

LIU, X.; See GAO, R.

MAALEK GHAINI, F. M.; See NILI AHMADABADI, M.

MAHALE, P. and NAIR, M. T.; Iterated Lavrentiev regularization for nonlinear ill-posed problems

MANAM, S. R.; Scattering of membrane coupled gravity waves by partial vertical barriers

MORIYA, K., ZHANG, L. and NODERA, T.; An approximate matrix inversion procedure by parallelization of the Sherman-Morrison formula

NAIR, M. T.; See MAHALE, P.

NI, Z.; See LI, M.

NILI AHMADABADI, M. and MAALEK GHAINI, F. M.; An Adomian decomposition method for solving Liénard equations in general form

NODERA, T.; See MORIYA, K.

OGUNYE, O. R.; See AGUSTO, F. B.

ÖZUĞURLU, E.; A note on the numerical approach for the reaction-diffusion problem with a free boundary condition

PEČARIĆ, J.; See AGLIĆ ALJINOVIĆ, A.

QIAN, Y. and LIN, X.; Ruin probabilities under an optimal investment and proportional reinsurance policy in a jump diffusion risk process

RIBIČIĆ PENAVA, M.; See AGLIĆ ALJINOVIĆ, A.

SALAHI, M.; A self-regular Newton based algorithm for linear optimization

SELLIER, M. and LENZ, R. D.; A note on approximate benchmark solutions for viscous two-layer flows

ŠEVČOVIČ, D.; See LAUKO, M.

SHI, Y. J.; See LI, R.

SHIFERAW, M.; See SRINIVASACHARYA, D. 
SRINIVASACHARYA, D. and SHIFERAW, M.; Magnetohydrodynamic flow of a micropolar fluid in a circular pipe with Hall effects

SWEILAM, N. H. and KHADER, M. M.; A Chebyshev pseudo-spectral method for solving fractional-order integro-differential equations

TEO, K. L.; See LI, B.

VAN BRUNT, B. and VLIEG-HULSTMAN, M.; An eigenvalue problem involving a functional differential equation arising in a cell growth model

VLIEG-HULSTMAN, M.; See VAN BRUNT, B.

WHITEN, B.; A simple algorithm for deduction

YU, Z.-X. and YUAN, R.; Travelling wave solutions in nonlocal reactiondiffusion systems with delays and applications

YUAN, R.; See YU, Z.-X.

ZHANG, L.-H. and WANG, Y.; A note on periodic solutions of a forced Liénard-type equation 


\section{PREPARATION OF MANUSCRIPTS}

The ANZIAM Journal is typeset in LTEX. Style files are available from http://www . austms . org . au/ Publ/ANZIAM/authorinfo.shtml.

The manuscript should conform to the following rules. In case of any doubt, authors are advised to refer to previous papers in the Journal.

1. Abstract, title and author details. An abstract not exceeding 300 words should be included in the manuscript. If the title is long, supply also a shortened form of the title not exceeding 40 characters, including spaces. Addresses should be shown under the authors name, including e-mail address if available.

2. Main headings. Main headings should be numbered, centred and shown thus:

\section{Preliminary results}

3. Theorems. The titles Lemma, Theorem, Corollary, Remark, Definition etc. should be left-justified and numbered consecutively with arabic numerals, e.g.

LEMMA 1.1. The content of the lemma, theorem etc. should follow, as here.

4. Acknowledgements. If acknowledgements of support and assistance are made, these should be given at the end of the article. Footnotes should be avoided.

5. Equations. Equations should be punctuated to conform to their place in the syntax of the sentence. Equation numbers should be shown on the right in round brackets.

6. References. The reference list should be in ALPHABETICAL ORDER by name of first author, preceded by a reference number in square brackets. These references should be cited in the text by giving the appropriate number in square brackets. The following layout for books, journal articles, theses, articles in books, and conference proceedings respectively, must be followed.

[1] M. Abramowitz and I. A. Stegun (eds), Handbook of mathematical functions (Dover, New York, 1970).

[2] S. N. Biswas and T. S. Santhanam, "Coherent states of para-Bose oscillators", J. Austral. Math. Soc. Ser. B 22 (1980) 210-217.

[3] F. H. Busse, "On the mean field problem of thermal convection", Max-Plank Inst. Phys. Astrophys. Rep. MPI-PAE/Astro 31 (1970) 1-31.

[4] E. M. Casling, "Slender planing surfaces", Ph. D. Thesis, University of Adelaide, 1978.

[5] R. H. Day, "Adaptive process and economic theory", in Adaptive economic models (eds R. H. Day and T. Groves), (Academic Press, New York, 1975) 1-38.

[6] J. W. Miles, "Resonant response of harbors (the harbor paradox revisited)", Proc. 8th Symp. Naval Hydro. (1970) 95-115.

7. Tables. Each should be preceded by a caption beginning: TABLE 1 (or 2, 3, etc.)

8. Figures. Each figure should have a caption beginning: FIgURE 1 (or 2, 3, etc.).

Authors should provide diagrams drawn to professional standards in the form of encapsulated Postscript files. Other forms of diagrams drawn to professional standard may be acceptable, however this may also necessitate a payment from the author(s) to cover additional cost involved in processing them. 


\section{SUBMISSION OF MANUSCRIPTS}

Prior to submission authors are asked to read the section "Preparation of Manuscripts" on the previous page.

Authors of articles submitted for publication in The ANZIAM Journal are asked to ensure that their manuscripts are in a form suitable for sending to the printer. Editors reserve the right to return poorly presented material to authors for revision.

The author should submit a pdf file if possible to the Online Journal System. Follow the instructions at http://anziamj.austms.org.au/ojs/index.php/ANZIAMJ/user/register.

It will speed up processing of accepted papers if a $\mathrm{LT}_{\mathrm{E}} \mathrm{X}$ version of the manuscript is available. It is not necessary to send such a file with the submitted paper. This will be requested if the paper is accepted.

Authors of accepted papers will be provided with a complimentary electronic version of their paper as published.

Excessive costs incurred by the Australian Mathematical Society through corrections to or withdrawal of articles may be charged to the authors concerned.

Submission of a paper to The ANZIAM Journal is a representation by the author that the manuscript has not been copyrighted or published, and that it is not being considered for publication elsewhere.

\section{THE ANZIAM JOURNAL AND THE ELECTRONIC SUPPLEMENT}

The Journal of the Australian Mathematical Society began publication in 1959, and from 1975 appeared in two series, Series A (Pure Mathematics and Statistics) and Series B (Applied Mathematics). Series B is now The ANZIAM Journal and is published in volumes comprising four quarterly parts. There is also a fifth (electronic) part designed for rapid publication (http://anziamj . austms .org. au/ojs/index.php/ANZIAMJ). The Editor-in-Chief is A. J. Roberts, School of Mathematical Sciences, The University of Adelaide, ADELAIDE, SA 5005; anthony.roberts@adelaide.edu.au. All five parts are refereed. All accepted papers have the option of publication in the electronic part.

It is the editorial policy of The ANZIAM Journal to consider papers in any field of applied mathematics and related mathematical sciences. Novel applications of mathematics in real situations are especially welcome. All papers must include some indication of applicability, and an introduction that can be understood by non-specialist readers from the whole applied mathematical community. 


\section{CAMBRIDGE}

\section{JOURNALS}

\section{Journal of Fluid Mechanics}

Editor

M. G. Worster, University of Cambridge, UK

Journal of Fluid Mechanics is the leading international journal in the field and is essential reading for all those concerned with developments in fluid mechanics. It publishes authoritative articles covering theoretical, computational and experimental investigations of all aspects of the mechanics of fluids. Each issue contains papers on both the fundamental aspects of fluid mechanics, and their applications to other fields such as aeronautics, astrophysics, physiology, chemical and mechanical engineering, hydraulics, meteorology, oceanography, geology, acoustics and combustion.

\section{Price information}

is available at: http://journals.cambridge.org/flm

\section{Free email alerts}

Keep up-to-date with new material - sign up at http://journals.cambridge.org/flm-alerts

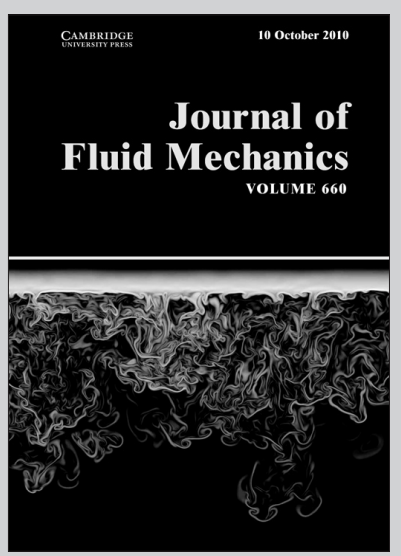

Journal of Fluid Mechanics is available online at: http://journals.cambridge.org/flm

To subscribe contact Customer Services

\section{in Cambridge:}

Phone +44 (0)1223 326070

Fax +44 (0)1223 325150

Email journals@cambridge.org

\section{in New York:}

Phone +1 (845) 3537500

Fax +1 (845) 3534141

Email

subscriptions_newyork@cambridge.org

For free online content visit: http://journals.cambridge.org/flm
CAMBRIDGE UNIVERSITY PRESS 


\section{CAmbridge}

\section{JOURNALS}

\section{Glasgow Mathematical Journal}

Published for

The Glasgow Mathematical Journal Trust

\section{Editor-in-Chief}

I. A. B. Strachan, University of Glasgow, UK

Glasgow Mathematical Journal publishes original research papers in any branch of pure and applied mathematics. An international journal, its policy is to feature a wide variety of research areas, which in recent issues have included ring theory, group theory, functional analysis, combinatorics, differential equations, differential geometry, number theory, algebraic topology, and the application of such methods in applied mathematics.

\section{Price information}

is available at: http://journals.cambridge.org/gmj

\section{Free email alerts}

Keep up-to-date with new material - sign up at http://journals.cambridge.org/gmj-alerts

For free online content visit: http://journals.cambridge.org/gmj

To subscribe contact Customer Services

\section{in Cambridge:}

Phone +44 (0)1223 326070

Fax +44 (0)1223 325150

Email journals@cambridge.org

\section{in New York:}

Phone +1 (845) 3537500

Fax $+1(845) 3534141$

Email

subscriptions_newyork@cambridge.org 


\section{CAMBRIDGE JURNALS}

\section{European Journal of Applied Mathematics}

\section{Co-Editors-in-Chief}

S. D. Howison, University of Oxford, UK

A. A. Lacey, DPMMS, Heriot-Watt University, UK

M. J. Ward, University of British Columbia, Canada

Since 2008 EJAM surveys have been expanded to cover Applied and Industrial Mathematics. Coverage of the journal has been strengthened in probabilistic applications, while still focusing on those areas of applied mathematics inspired by real-world applications, and at the same time fostering the development of theoretical methods with a broad range of applicability. Survey papers contain reviews of emerging areas of mathematics, either in core areas or with relevance to users in industry and other disciplines. Research papers may be in any area of applied mathematics, with special emphasis on new mathematical ideas, relevant to modelling and analysis in modern science and technology, and the development of interesting mathematical methods of wide applicability.

\section{Price information}

is available at: http://journals.cambridge.org/ejm

\section{Free email alerts}

Keep up-to-date with new material - sign up at http://journals.cambridge.org/ejm-alerts

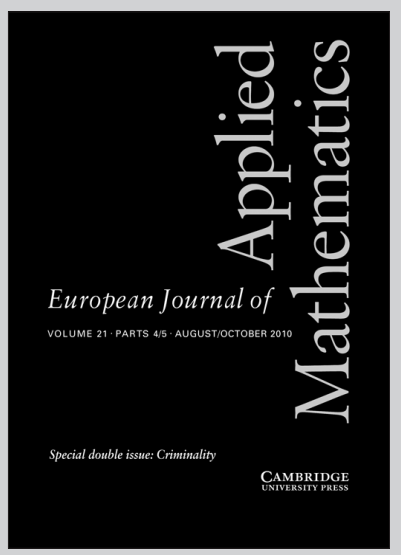

European Journal of Applied Mathematics

is available online at: http://journals.cambridge.org/ejm

To subscribe contact Customer Services

\section{in Cambridge:}

Phone +44 (0)1223 326070

Fax $+44(0) 1223325150$

Email journals@cambridge.org

in New York:

Phone +1 (845) 3537500

Fax +1 (845) 3534141

Email

subscriptions_newyork@cambridge.org 


\section{CAMBRIDGE JOURALS}

\section{Proceedings of the Edinburgh \\ Mathematical Society}

Published for

The Edinburgh Mathematical Society

\section{Editorial Management}

The Secretary, ICMS, Edinburgh, UK

The Edinburgh Mathematical Society was founded in 1883 and over the years, has evolved into the principal society for the promotion of mathematics research in Scotland. The Society has published its Proceedings since 1884. This journal contains research papers on topics in a broad range of pure and applied mathematics, together with a number of topical book reviews.

\section{Price information}

is available at: http://journals.cambridge.org/pem

\section{Free email alerts}

Keep up-to-date with new material - sign up at http://journals.cambridge.org/pem-alerts

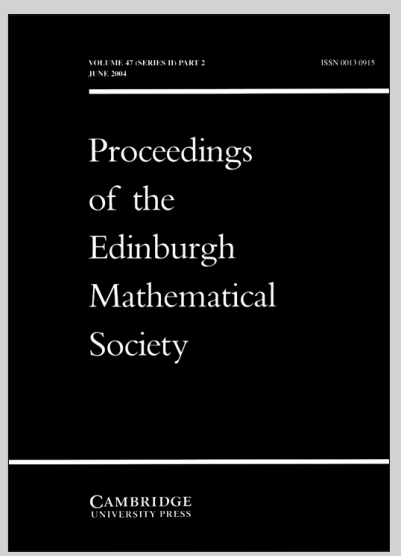

Proceedings of the Edinburgh Mathematical Society is available online at: http://journals.cambridge.org/pem

To subscribe contact Customer Services

\section{in Cambridge:}

Phone +44 (0)1223 326070

Fax +44 (0)1223 325150

Email journals@cambridge.org

\section{in New York:}

Phone +1 (845) 3537500

Fax +1 (845) 3534141

Email

subscriptions_newyork@cambridge.org

For free online content visit: http://journals.cambridge.org/pem 


\section{CAMBRIDGE}

\section{JOURNALS}

\section{Mathematical Proceedings of the Cambridge Philosophical Society}

Published for

The Cambridge Philosophical Society

\section{Editor}

G. P. Paternain, University of Cambridge, UK

Mathematical Proceedings is one of the few high-quality journals publishing original research papers that cover the whole range of pure and applied mathematics, theoretical physics and statistics. All branches of pure mathematics are covered, in particular logic and foundations, number theory, algebra, geometry, algebraic and geometric topology, classical and functional analysis, differential equations, probability and statistics. On the applied side, mechanics, mathematical physics, relativity and cosmology are included.

\section{Price information}

is available at: http://journals.cambridge.org/psp

\section{Free email alerts}

Keep up-to-date with new material - sign up at http://journals.cambridge.org/psp-alerts

For free online content visit: http://journals.cambridge.org/psp

To subscribe contact Customer Services

\section{in Cambridge:}

Phone +44 (0)1223 326070

Fax +44 (0)1223 325150

Email journals@cambridge.org

\section{in New York:}

Phone +1 (845) 3537500

Fax +1 (845) 3534141

Email

subscriptions_newyork@cambridge.org 


\section{CAMBRIDGE}

\section{JOURNALS}

\section{Proceedings of the Royal Society of Edinburgh, Section A: Mathematics}

Marketed and Distributed for the Royal Society of Edinburgh

\section{Chairman and Executive Editor}

B. P. Rynne, Heriot-Watt University, UK

A flagship publication of The Royal Society of Edinburgh, Proceedings $A$ is a prestigious, general mathematics journal publishing peer-reviewed papers of international standard across the whole spectrum of mathematics, but with the emphasis on applied analysis and differential equations. An international journal, publishing six issues per year, Proceedings A has been publishing the highestquality mathematical research for nearly 70 years. Recent issues have included a wealth of key contributors and considered research papers.

\section{Price information}

is available at: http://journals.cambridge.org/prm

\section{Free email alerts}

Keep up-to-date with new material - sign up at http://journals.cambridge.org/prm-alerts

For free online content visit: http://journals.cambridge.org/prm

To subscribe contact Customer Services

\section{in Cambridge:}

Phone +44 (0)1223 326070

Fax +44 (0)1223 325150

Email journals@cambridge.org

in New York:

Phone +1 (845) 3537500

Fax +1 (845) 3534141

Email

subscriptions_newyork@cambridge.org 
President: $\quad$ Professor N. JOSHI

Secretary:

Treasurer:
P. J. STACEY

Dr A. Howe
School of Mathematics and Statistics

The University of Sydney

NSW 2006, Australia

Department of Mathematics and Statistics

La Trobe University

Bundoora Victoria 3086, Australia

Mathematics Department

Mathematical Sciences Institute

The Australian National University

Canberra ACT 0200, Australia

Membership and correspondence: Applications for membership, notices of changes of address or title or position, members' subscriptions and correspondence related to accounts should be sent to the Treasurer. All other correspondence should be sent to the Secretary.

Subscriptions: Four parts are planned for 2010. Subscription prices for 2010 are $£ 223$ (\$427 in USA, Canada and Mexico) which includes print and electronic access. The electronic-only access price for 2010 is $£ 191$ ( $\$ 365$ in USA, Canada and Mexico). Single parts cost $£ 60$ (\$117 in USA, Canada and Mexico). Prices include delivery by air where appropriate. EU subscribers who are not registered for VAT should add VAT at their country's rate. VAT registered subscribers should provide their VAT registration number. Orders, which must be accompanied by payment, should be sent to a subscription agent, book-seller, or direct to the publishers: Cambridge University Press, The Edinburgh Building, Shaftesbury Road, Cambridge CB2 8RU or, in the USA, Canada and Mexico, Cambridge University Press, Journals Fulfilment Department, 100 Brook Hill Drive, West Nyack, NY 10994-2133. Japanese prices are available from Kinokuniya Company Ltd, PO Box 55, Chitose Tokyo 156, Japan. Periodicals postage is paid at New York, NY and additional mailing offices. POSTMASTER: send address changes in USA, Canada and Mexico to The ANZIAM JOURNAL Cambridge University Press, Journals Fulfilment Department, 100 Brook Hill Drive, West Nyack, NY 10994-2133.

This journal is included in the Cambridge Journals Online service. Further information, and online access for subscribers, is available at http://journals.cambridge.org/anz

Copying: This journal is registered with the Copyright Clearance Centre, 222 Rosewood Drive, Danvers, MA 01923, USA. Organizations in the USA who are registered with the CCC may therefore copy materials beyond the limits permitted by sections 107 and 108 of US copyright law subject to payment to CCC of the per-copy fee of $\$ 16.00$. This consent does not extend to multiple copying for promotional and commercial purposes. Code 1446-1811/2010 \$16.00.

Organizations authorized by the Copyright Licensing Agency may also copy material subject to the usual conditions. For all other use, permission should be sought from Cambridge or the American branch of Cambridge University Press.

Published by Cambridge University Press for the Australian Mathematical Publishing Association Incorporated. Printed in the United Kingdom at Bell \& Bain Ltd, Glasgow.

(C) 2010 Australian Mathematical Publishing Association Inc.

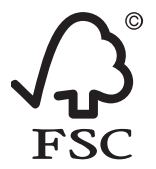
forests and other controlled sources www.fsc.org Cert no. TT-COC-002769 (c) 1996 Forest Stewardship Council
This journal issue has been printed on FSC-certified paper and cover board. FSC is an independent, non-governmental, not-for-profit organization established to promote the responsible management of the world's forests. Please see www.fsc.org for information. 


\section{Table of Contents}

An eigenvalue problem involving a functional differential equation arising in a cell growth model

van Brunt, B. Ẽ Vlieg-Hulstman, $M$.

Avian influenza optimal seasonal vaccination strategy

Agusto, F. B. E Ogunye, O. R.

A note on approximate benchmark solutions for viscous two-layer flows

Sellier, M. E Lenz, R. D.

Exact solutions for the Poiseuille flow of a generalized Maxwell fluid induced by time-dependent shear stress

Akhtar, W., Fetecau, C. Eं Awan, A. U.

Comparison of numerical and analytical approximations of the early exercise boundary of American put options

Lauko, M. Ẽ Ševčovič, $D$.

Optimal proportional reinsurance under two criteria: maximizing the expected utility and minimizing the value at risk

Liang, Z. $\mathcal{E}$ Guo, J.

A Chebyshev pseudo-spectral method for solving fractional-order integrodifferential equations

Sweilam, N. H. E Khader, M. M.

A primal-dual interior-point algorithm based on a new kernel function

Cho, G. M., Cho, Y. Y. E Lee, Y. H.

Author Index 